\title{
Direct effects of $\mathrm{CO}_{2}$ concentration on growth and isotopic composition of marine plankton
}

\author{
By DIETER A. WOLF-GLADROW*, ULF RIEBESELL, STEFFEN BURKHARDT and JELLE \\ BIJMA, Alfred Wegener Institute for Polar and Marine Research, Postfach 120161 , \\ D-27515 Bremerhaven, Germany
}

(Manuscript received 16 December 1997; in final form 14 September 1998)

\begin{abstract}
The assessment of direct effects of anthropogenic $\mathrm{CO}_{2}$ increase on the marine biota has received relatively little attention compared to the intense research on $\mathrm{CO}_{2}$-related responses of the terrestrial biosphere. Yet, due to the rapid air-sea gas exchange, the observed past and predicted future rise in atmospheric $\mathrm{CO}_{2}$ causes a corresponding increase in seawater $\mathrm{CO}_{2}$ concentrations, $\left[\mathrm{CO}_{2}\right]$, in upper ocean waters. Increasing $\left[\mathrm{CO}_{2}\right]$ leads to considerable changes in the surface ocean carbonate system, resulting in decreases in $\mathrm{pH}$ and the carbonate concentration, $\left[\mathrm{CO}_{3}^{2-}\right]$. These changes can be shown to have strong impacts on the marine biota. Here we will distinguish between $\mathrm{CO}_{2}$-related responses of the marine biota which (a) potentially affect the ocean's biological carbon pumps and (b) are relevant to the interpretation of diagnostic tools (proxies) used to assess climate change on geological times scales. With regard to the former, three direct effects of increasing $\left[\mathrm{CO}_{2}\right]$ on marine plankton have been recognized: enhanced phytoplankton growth rate, changing elemental composition of primary produced organic matter, and reduced biogenic calcification. Although quantitative estimates of their impacts on the oceanic carbon cycle are not yet feasible, all three effects increase the ocean's capacity to take up and store atmospheric $\mathrm{CO}_{2}$ and hence, can serve as negative feedbacks to anthropogenic $\mathrm{CO}_{2}$ increase. With respect to proxies used in paleo-reconstructions, $\mathrm{CO}_{2}$-sensitivity is found in carbon isotope fractionation by phytoplankton and foraminifera. While $\mathrm{CO}_{2^{-}}$ dependent isotope fractionation by phytoplankton may be of potential use in reconstructing surface ocean $p \mathrm{CO}_{2}$ at ancient times, $\mathrm{CO}_{2}$-related effects on the isotopic composition of foraminiferal shells confounds the use of the difference in isotopic signals between planktonic and benthic shells as a measure for the strength of marine primary production. The latter effect also offers an alternative explanation for the large negative swings in $\delta^{13} \mathrm{C}$ of foraminiferal calcite between glacial and interglacial periods. Changes in $\left[\mathrm{CO}_{3}^{2-}\right]$ affect the $\delta^{18} \mathrm{O}$ in foraminiferal shells. Taking this into account brings sea surface temperature estimates for the glacial tropics closer to those obtained from other geochemical proxies.
\end{abstract}

\section{Introduction}

The increasing partial pressure of $\mathrm{CO}_{2}$ in the atmosphere leads to a corresponding increase in dissolved molecular $\mathrm{CO}_{2}$ concentrations, $\left[\mathrm{CO}_{2}\right]$, in the surface ocean on time scales of less than

* Corresponding author.

E-mail: wolf@awi-bremerhaven.de one year. Thus, higher atmospheric $\mathrm{CO}_{2}$ levels can almost immediately affect marine plankton. In order to distinguish such fast effects from the influences associated with dissolution of calcium carbonate in sediments or $\mathrm{CO}_{2}$-related changes in ocean circulation, they will be called "direct effects". Research on direct effects of increasing atmospheric $\mathrm{CO}_{2}$ on land plants and ecosystems is well established. The bibliography by Strain 
and Cure (1994) contains approximately 800 references on this topic published between 1980 and 1994. In comparison, very few investigations have dealt with $\mathrm{CO}_{2}$-related effects in the marine environment.

Until recently, carbon has been mostly ignored as a factor influencing the growth and elementary composition of marine plankton because dissolved inorganic carbon (DIC) is always available in excess of carbon demand by plankton. RUBISCO, the dominant carboxylating enzyme in marine phytoplankton, however, requires molecular $\mathrm{CO}_{2}$ as inorganic carbon source (Cooper et al., 1969). Although $\mathrm{CO}_{2}$ is replenished by conversion from $\mathrm{HCO}_{3}^{-}$, this process is too slow relative to photosynthetic carbon fixation in order to satisfy cellular carbon demand (Wolf-Gladrow and Riebesell, 1997). As a result, only a small fraction of DIC is actually available for carbon uptake by an algal cell on short time scales. Although the importance of the enzyme carbonic anhydrase to speed up the slow conversion between $\mathrm{HCO}_{3}^{-}$and $\mathrm{CO}_{2}$ is still unresolved, the kinetic inertia of the carbonate system with respect to resupply of $\mathrm{CO}_{2}$ from the large DIC pool implies that phytoplankton may in fact be sensitive to changes in seawater $\mathrm{CO}_{2}$ concentrations.

The isotopic compositions $\left(\delta^{11} \mathrm{~B}, \delta^{13} \mathrm{C}, \delta^{18} \mathrm{O}\right)$ of foraminiferal calcite are used as paleo proxies for the reconstruction of $\mathrm{pH}$, primary productivity, and seawater temperature in ancient oceans. Only recently it has been discovered that carbon and oxygen isotope compositions of foraminiferal shells vary with the carbonate $\left(\mathrm{CO}_{3}^{2-}\right)$ concentration in seawater (Spero et al., 1997). In view of the considerable changes in the surface water carbonate system with a related change in $\mathrm{CO}_{3}^{2-}$ concentrations between glacial and interglacial times, these findings require reinterpretation of foraminiferal isotopic signals from the geological record.

The intention of this paper is to summarize recent evidence for direct effects of $\mathrm{CO}_{2}$ on plankton in combination with new findings, to discuss the mechanisms involved and their interrelations, and to estimate their possible impact on carbon uptake by the oceans and on the interpretation of paleo proxies.

\section{The carbonate system in the sea}

The carbonate system in the sea encompasses three species of dissolved inorganic carbon (DIC), namely molecular dissolved $\mathrm{CO}_{2}$ (or aqueous carbon dioxide, $\mathrm{CO}_{2}(\mathrm{aq})$, which will be referred to simply as $\mathrm{CO}_{2}$ ), $\mathrm{HCO}_{3}^{-}$(bicarbonate) and $\mathrm{CO}_{3}^{2-}$ (carbonate), as well as $\mathrm{H}^{+}, \mathrm{OH}^{-}$and some minor components such as $\mathrm{B}(\mathrm{OH})_{3}$ and $\mathrm{B}(\mathrm{OH})_{4}^{-}$. The relative amounts of the three DIC species are a function of $\mathrm{pH}$. At typical seawater $\mathrm{pH}$ of $8.2,90 \%$ is present in the form of $\mathrm{HCO}_{3}^{-}$, $9 \%$ as $\mathrm{CO}_{3}^{2-}$, and less than $1 \%$ as $\mathrm{CO}_{2}$.

\subsection{Anthropogenic effects on surface ocean $p H$}

Since 1800 the $\mathrm{pH}$ in surface waters has decreased by ca. 0.1 units due to increased atmospheric $\mathrm{CO}_{2}$ levels (Fig. 1; compare Brewer, 1997). In the IS92a scenario of the IPCC report (1995), it is assumed that anthropogenic $\mathrm{CO}_{2}$ emissions increase almost linearly up to $20 \mathrm{GtC} \mathrm{yr}^{-1}$ in the year 2100 . The future atmospheric $\mathrm{CO}_{2}$ concentrations can be estimated by a linear response model (Hasselmann et al., 1996) in which parameters are based on global carbon cycle models by MaierReimer and Hasselmann (1987) and Maier-Reimer (1993). The atmospheric $\mathrm{CO}_{2}$ concentration is expected to triple compared to preindustrial time shortly after the year 2100 , and accordingly, the $\mathrm{pH}$ in the surface ocean will approach 7.8.

\subsection{Algal blooms}

During blooms of non-calcifying microalgae, the DIC concentration decreases and the $\mathrm{pH}$ increases appreciably. These changes of the carbonate system are independent of the carbon source $\left(\mathrm{CO}_{2}, \mathrm{HCO}_{3}^{-}\right.$or both) of the algae. The decrease in DIC is limited by other nutrients (phosphate, nitrate) or other factors (light, grazing, micronutrients) to less than $15 \%$ (Codispoti et al., 1982). When DIC decreases from $2000 \mathrm{mmol}$ $\mathrm{m}^{-3}$ to $1800 \mathrm{mmol} \mathrm{m}^{-3}$ at total alkalinity 2300 mequiv $^{-3}, \quad T=15^{\circ} \mathrm{C}, \quad S=35$, the $\mathrm{pH}$ increases from 8.2 to 8.5 and $\mathrm{CO}_{2}$ decreases from $10 \mathrm{mmol} \mathrm{m}^{-3}$ to $4 \mathrm{mmol} \mathrm{m}^{-3}$.

Calcifying organisms such as coccolithophorids, foraminifera or corals change both DIC and total alkalinity. Total alkalinity (TA) is defined by:

$$
\begin{aligned}
\mathrm{TA}= & {\left[\mathrm{HCO}_{3}^{-}\right]+2\left[\mathrm{CO}_{3}^{2-}\right]+\left[\mathrm{OH}^{-}\right]-\left[\mathrm{H}^{+}\right] } \\
& +\left[\mathrm{B}(\mathrm{OH})_{4}^{-}\right] \\
& + \text {minor constituents }
\end{aligned}
$$

(compare Dickson, 1981, for details). Calcification 


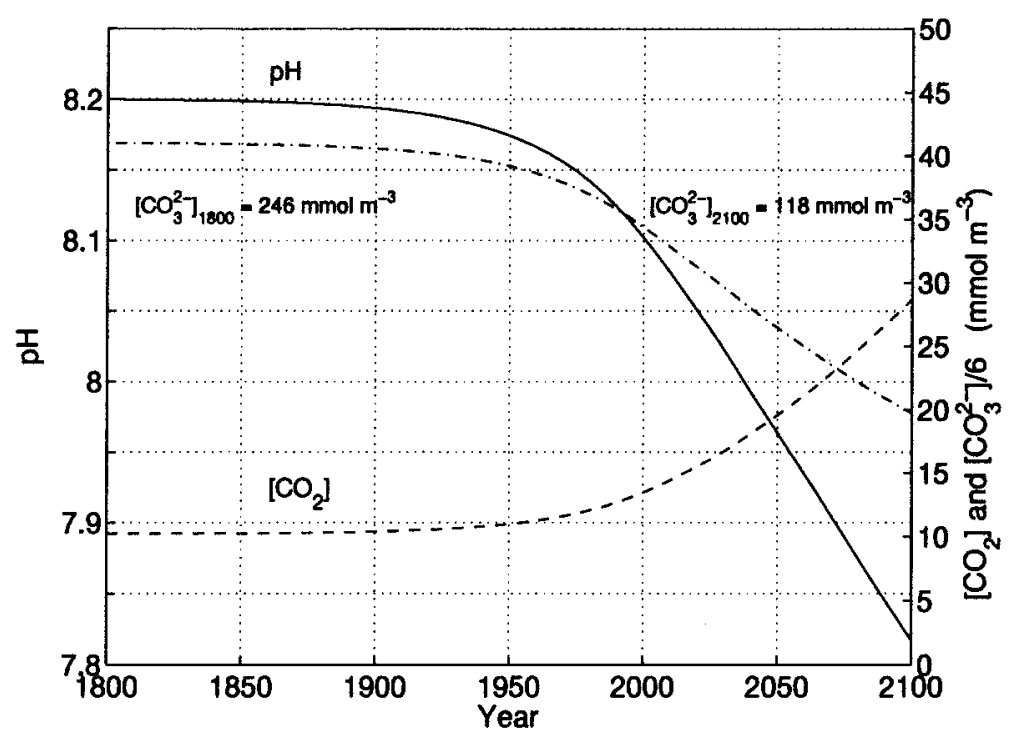

Fig. 1. Changes in the surface ocean carbonate system in response to an atmospheric $\mathrm{CO}_{2}$ increase according to IS92a scenario of the IPCC report 1995 (approximated by a linear increase of $\mathrm{CO}_{2}$ emissions from $6.3 \mathrm{GtC}^{\mathrm{yr}}{ }^{-1}$ to $20 \mathrm{GtC} \mathrm{yr}^{-1}$ in the year 2100): $\mathrm{pH}$ (solid line), $\mathrm{CO}_{2}$ concentration (dashed line) and $\mathrm{CO}_{3}^{2-}$ concentration (dashdotted line; please note the different scales for $\mathrm{CO}_{2}$ and $\mathrm{CO}_{3}^{2-}$ ).

according to

$\mathrm{Ca}^{2+}+\mathrm{CO}_{3}^{2-} \rightarrow \mathrm{CaCO}_{3}$

or

$\mathrm{Ca}^{2+}+2 \mathrm{HCO}_{3}^{-} \rightarrow \mathrm{CaCO}_{3}+\mathrm{CO}_{2}+\mathrm{H}_{2} \mathrm{O}$

changes DIC and TA in the ratio $1: 2$. A calcifying alga with a rate of photosynthesis $\alpha$ and a rate of calcification $\beta$ changes DIC and TA in the ratio $(\alpha+\beta) / 2 \beta$. The rain ratio parameter

$\gamma=\frac{1}{2} \frac{\mathrm{d}[\mathrm{TA}]}{\mathrm{d}[\mathrm{DIC}]} \approx \frac{\beta}{\alpha+\beta}$

thus varies between zero (photosynthesis alone) and one (calcification alone). The Revelle or buffer factor, $\mathrm{RF}$, is defined as the relative change in $\mathrm{CO}_{2}$ divided by the relative change in DIC

$\mathrm{RF}:=\frac{\mathrm{d}\left[\mathrm{CO}_{2}\right]}{\left[\mathrm{CO}_{2}\right]} / \frac{\mathrm{d}[\mathrm{DIC}]}{[\mathrm{DIC}]}$.

DIC decreases due to photosynthesis, calcification, and any combination of those two processes, the change in $\mathrm{CO}_{2}$ can be positive or negative depending on the rain ratio parameter $\gamma$. In noncalcifying blooms $(\gamma \approx 0)$ the $\mathrm{RF}$ is approximately 10 which means that reduction of $\mathrm{CO}_{2}$ to half its original value is associated with a decrease of (only) $5 \%$ in DIC. On the other hand, a doubling of $\mathrm{CO}_{2}$ due to higher atmospheric $p \mathrm{CO}_{2}$ results in (only) a $10 \%$ increase in DIC. In calcifying blooms RF is smaller and for $\gamma>0.6$ the Revelle factor becomes negative which means that $\mathrm{CO}_{2}$ increases while DIC decreases: calcification leads to an increase in $\mathrm{CO}_{2}$ (a counter-intuitive result!). Such high values of $\gamma$ can occur, for example, in intense blooms of coccolithophorids (Robertson et al., 1994).

\subsection{Kinetics and carbonic anhydrase}

The reactions of the various compounds of the carbonate system are very fast (diffusion controlled) with one exception: the conversion between $\mathrm{CO}_{2}$ and $\mathrm{HCO}_{3}^{-}$is slow $(\tau \approx 30 \mathrm{~s}$ based on a rate constant of $0.036 \mathrm{~s}^{-1}$, Johnson, 1982). Many organisms (from microalgae to mammals) use the zinc-containing enzyme carbonic anhydrase (CA) to speed up this conversion. Please note that catalysis by CA provides a net conversion in one or the other direction only when the system is out of chemical equilibrium such as, for example, in the diffusive boundary layer around an alga or 
inside the cell where metabolic processes maintain non-equilibrium states. Thus, the net rate of conversion from $\mathrm{HCO}_{3}^{-}$to $\mathrm{CO}_{2}$ cannot be estimated from measurements of carbonic anhydrase activity (no net conversion at high CA activity in an equilibrium situation).

\section{Direct effects}

The distribution of dissolved inorganic carbon in the oceans shows relatively low values in the mixed layer and higher levels in the deep ocean which increase from the North Atlantic to the Southern Ocean and the North Pacific (Takahashi, 1989). This distribution is due to DIC pumps which are defined as processes that deplete the ocean surface of DIC relative to the deep-water DIC (Volk and Hoffert, 1985). Three pumps are distinguished: the carbonate pump, the soft-tissue pump, and the solubility (or physical) pump. The first two result from the flux of biogenically precipitated $\mathrm{CaCO}_{3}$ and of photosynthetically produced organic material from the ocean's surface. The physical pump results from increased $\mathrm{CO}_{2}$ solubility in downwelling cold water. The transport of $\mathrm{CaCO}_{3}$ out of the surface ocean changes DIC and TA in the ratio $1: 2(\gamma=1)$ and thereby increases $\mathrm{CO}_{2}$ in surface water. Therefore the $\mathrm{CaCO}_{3}$ pump is sometimes referred to as a counter pump because of its effect on $\mathrm{CO}_{2}$. Several authors have analyzed the strengths of the different DIC pumps. Volk and Hoffert (1985) find that results of an abiotic box model cannot explain observed DIC profiles. Sarmiento et al. (1995) compare GEOSECS observations with results of a threedimensional ocean carbon cycle model. They conclude that $75 \%$ of the vertical gradients in DIC are due to the biological pump (soft-tissue plus carbonate pump). The influence of the biological pump is shown by a model experiment performed by Maier-Reimer et al. (1996) in which marine biological production was stopped completely at one instant resulting in nearly a doubling of the atmospheric $\mathrm{CO}_{2}$ concentration. Based on these findings it is important to investigate whether the strength of the biological carbon pump is affected by anthropogenic perturbations. Three of the direct effects discussed here (increase in growth rate, shift in elementary composition, and decrease in calcification rate) are of potential importance for the strengths of the soft-tissue and the carbonate pumps.

Direct effects on the isotopic fractionation in microalgae and foraminifera enable us to use isotopic composition (of parts) of these organisms as a diagnostic tool. Their main application is the reconstruction of various paleo-quantities from sedimentary material. At the same time, isotopic fractionation in microalgae can also help to understand the mechanisms involved in two of the other direct effects (increase in growth rate, shift in elementary composition).

\subsection{Direct effects on the carbon pumps}

3.1.1. Growth rate of phytoplankton. The potential of direct effects of $\mathrm{CO}_{2}$ on marine phytoplankton growth in the natural environment is presently an issue of debate. Clearly, dissolved inorganic carbon concentrations, which are two to three orders of magnitude higher than those of other macronutrients ( $\mathrm{N}$ and $\mathrm{P}$ ) and are depleted by no more than $15 \%$ even by the most intense phytoplankton blooms (Codispoti et al., 1982), are always in ample supply. As outlined above, however, reactions within the carbonate system, particularly the interconversion between $\mathrm{HCO}_{3}^{-}$and $\mathrm{CO}_{2}$, are slow compared to rates of carbon uptake by marine phytoplankton. Conditions in the diffusive boundary layer around a photosynthesizing cell therefore deviate significantly from those in the bulk medium (see Wolf-Gladrow and Riebesell, 1997). Still, even for a cell restricted to $\mathrm{CO}_{2}$ uptake, the photosynthetic carbon demand in most cases will be met by the diffusive supply of $\mathrm{CO}_{2}$ from its environment (Wolf-Gladrow and Riebesell, 1997). In fact, at cell sizes representative for marine diatoms $(5-50 \mu \mathrm{m}$ in radius) and growth rates typically observed in natural populations $\left(0.5-1 \mathrm{~d}^{-1}\right)$, cellular carbon demand remains well below the potential $\mathrm{CO}_{2}$ supply from the bulk medium to the cell surface (Fig. 2). In addition to $\mathrm{CO}_{2}$ uptake, utilization of $\mathrm{HCO}_{3}^{-}$, either by direct $\mathrm{HCO}_{3}^{-}$uptake or catalyzed conversion of $\mathrm{HCO}_{3}^{-}$to $\mathrm{CO}_{2}$ via extracellular carbonic anhydrase, would tend to diminish or abolish potential effects of $\mathrm{CO}_{2}$ limitation. Why then should $\mathrm{CO}_{2}$ concentration have any effect on phytoplankton growth?

$\mathrm{CO}_{2}$-dependent growth was first reported for three species of marine diatoms, which showed a 


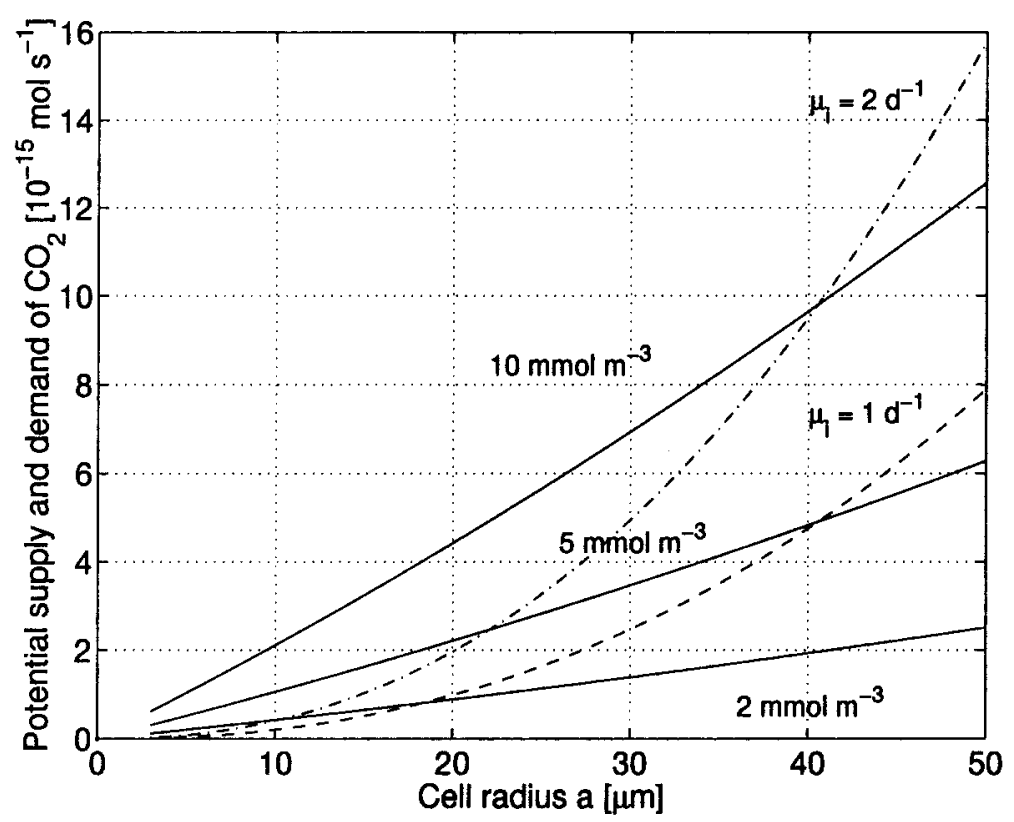

Fig. 2. Potential supply of $\mathrm{CO}_{2}$ from the bulk medium to the outer surface of an algal cell assuming diffusional transport of $\mathrm{CO}_{2}$ (solid lines) and demand of carbon by the cell for two instantaneous growth rates, $\mu_{i}$ (dashed lines) as a function of cell radius $a$. The carbon content, $\gamma$ (in mol C) of diatoms is calculated from cell volume, $V\left(\right.$ in $\left.\mu \mathrm{m}^{3}\right)$ by $\gamma=3.154 \times 10^{-14} V^{0.758}$ (Strathmann, 1967). The potential supply is proportional to $\left[\mathrm{CO}_{2}\right]_{\text {bulk }}$, whereas the actual $\mathrm{CO}_{2}$ flux is proportional to $\left(\left[\mathrm{CO}_{2}\right]_{\text {bulk }}-\left[\mathrm{CO}_{2}\right]_{\mathrm{a}}\right)$ where $\left[\mathrm{CO}_{2}\right]_{\text {bulk }}$ and $\left[\mathrm{CO}_{2}\right]_{\mathrm{a}}$ are the concentrations in the bulk medium and at the cell surface, respectively (Wolf-Gladrow and Riebesell, 1997).

decrease in cell division rate with decreasing $\mathrm{CO}_{2}$ at concentrations below about $10 \mathrm{mmol} \mathrm{m}^{-3}$ (Riebesell et al., 1993; Fig. 3). These results were corroborated by mesocosm experiments showing similar $\mathrm{CO}_{2}$-dependent changes in growth rate for mixed populations of marine phytoplankton (Chen and Durbin, 1994). Recently, Hein and Sand-Jensen (1997) reported significant effects of $\mathrm{CO}_{2}$ concentration on the rate of ${ }^{14} \mathrm{C}$ incorporation also in natural populations. During a transect in the North Atlantic, these authors changed the $\mathrm{CO}_{2}$ concentrations in seawater samples through the addition of $\mathrm{HCl}$ or $\mathrm{NaOH}$ to $1 / 3,3$ times, and about 10 times the ambient levels $\left(10 \mathrm{mmol} \mathrm{m}^{-3}\right)$, and found primary production to decrease by $25 \%$ at reduced levels and to increase by $15-20 \%$ under elevated $\mathrm{CO}_{2}$ concentrations. How do these findings reconcile with $\mathrm{CO}_{2}$ supply rates in excess of photosynthetic carbon demand under natural $\mathrm{CO}_{2}$ concentrations and reports of the potential for direct $\mathrm{HCO}_{3}^{-}$uptake or CA-catalyzed $\mathrm{HCO}_{3}^{-}$

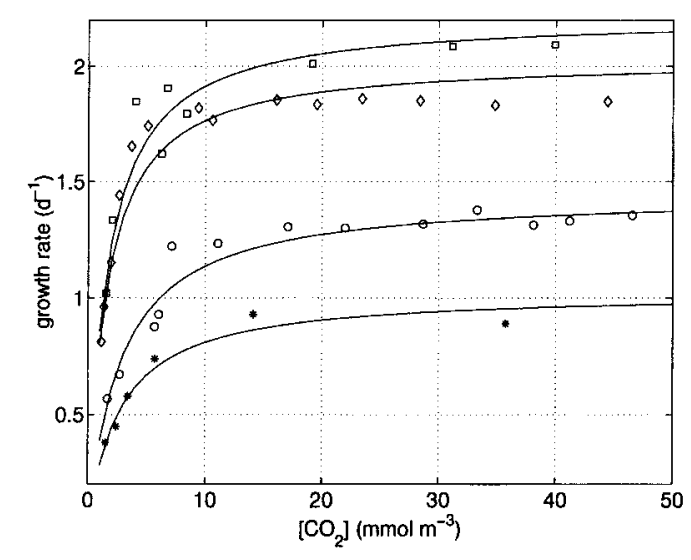

Fig. 3. The instantaneous growth rates $\mu_{i}$ of marine diatoms as a function of $\mathrm{CO}_{2}$-concentration: Ditylum brightwellii $(\diamond), \quad$ Thalassiosira punctigera $(\square)$, Rhizosolenia cf. alata $(\bigcirc)$, Coscinodiscus wailesii $(*)$ (data from Riebesell et al., 1993; Burkhardt, unpublished). 
conversion in various groups of marine phytoplankton?

Clearly, direct effects of $\mathrm{CO}_{2}$ on phytoplankton growth under natural conditions are to be expected only in cases where (1) $\mathrm{CO}_{2}$ is a significant or dominant source of inorganic carbon and (2) ambient levels of surface water $\mathrm{CO}_{2}$ concentrations are subsaturating photosynthetic $\mathrm{CO}_{2}$ fixation.

Surprisingly, the question of which form of inorganic carbon is predominantly utilized by natural marine phytoplankton is still open. Of the few species of marine microalgae examined so far, several showed the potential for direct uptake of $\mathrm{HCO}_{3}^{-}$(Burns and Beardall, 1987; Colman and Rotatore, 1995; Korb et al., 1997). In addition, the majority of marine phytoplankton species tested were found to have extracellular CA activity (Burns and Beardall, 1987; Morel et al., 1994; Roberts et al., 1997). In a recent study on mixed coastal diatom assemblages, in fact, Tortell et al. (1997) suggested that "bloom-forming diatoms use $\mathrm{HCO}_{3}^{-}$as a source of DIC ... and are not limited by $\mathrm{CO}_{2}$ availability." On the other hand, studies on stable carbon isotopes of marine microalgae (compare Subsection 3.2.1) suggest $\mathrm{CO}_{2-}$ dependence of photosynthetic isotope fractionation, even in those species for which extracellular $\mathrm{CA}$ activity or the ability for direct $\mathrm{HCO}_{3}^{-}$uptake were demonstrated (Hinga et al., 1994; Laws et al., 1995 and 1997). $\mathrm{CO}_{2}$-sensitivity was also observed in two strains of the coastal marine diatom Skeletonema costatum, for which the elemental composition $\mathrm{C}: \mathrm{N}: \mathrm{P}$ was found to change as a function of ambient $\mathrm{CO}_{2}$ concentration (Burkhardt and Riebesell, 1997; see Subsection 3.1.2)

With respect to the dominant carboxylating enzyme in marine diatoms, ribulose 1,5bisphosphate carboxylase-oxygenase (RUBISCO), point 2 above can easily be answered. With $\mathrm{CO}_{2}$ as the form of inorganic carbon fixed by RUBISCO and with its half-saturation concentration for $\mathrm{CO}_{2}$ ranging between 12 and $240 \mathrm{mmol} \mathrm{m}^{-3}$ (see review by Raven (1997)), seawater $\mathrm{CO}_{2}$ concentrations are far too low to saturate RUBISCO carboxylase activity. In order to have RUBISCO operate efficiently and cost effectively it appears essential for an algal cell to actively increase $\mathrm{CO}_{2}$ concentrations at the site of carboxylation (Raven, 1997). Although the func- tioning and location of such a carbon concentrating mechanism (CCM) is still unclear, its induction and regulation as a function of external $\mathrm{CO}_{2}$ concentrations has been demonstrated in various studies (for review, see Falkowski and Raven (1996)).

Obviously, the key to the question of how seemingly contradictory findings such as sufficient $\mathrm{CO}_{2}$ supply from the bulk medium, direct utilization of $\mathrm{HCO}_{3}^{-}$, and $\mathrm{CO}_{2}$-sensitivity of phytoplankton growth rate and elemental composition can be reconciled lies in the energy-dependence of active carbon acquisition. Since living in a potentially $\mathrm{CO}_{2}$-limiting environment due to the low $\mathrm{CO}_{2}$ affinity of RUBISCO, microalgae are obliged to spend energy in order to fuel their carbon concentrating mechanism(s). Whatever carbon source and pathway of carbon acquisition an alga uses, the increasing energetic cost of satisfying cellular carbon demand under low $\mathrm{CO}_{2}$ conditions is bound to affect the cell's overall performance. Thus, $\mathrm{CO}_{2}$ sensitivity of marine phytoplankton may be best viewed as co-limitation of $\mathrm{CO}_{2}$ in concert with energy availability and other factors controlling operation of the carbon concentrating mechanism.

Whereas one can easily imagine that biomass limitation will influence the strength of the softtissue pump, this is not necessarily the case for growth rate limitation. Faster growth may lead, however, to higher algal concentrations for short periods and thereby enhance the physical aggregation of phytoplankton which depends nonlinearly on the concentrations. Larger aggregates sink at speeds of about $100 \mathrm{~m} \mathrm{~d}^{-1}$ and can penetrate the winter mixed layer before being remineralized.

3.1.2. Effect of $\mathrm{CO}_{2}$ on the elemental composition $(C: P)$ of marine phytoplankton. Drawdown of atmospheric $\mathrm{CO}_{2}$ by the soft-tissue pump is driven by photosynthetic carbon fixation of marine phytoplankton and its subsequent export from the euphotic zone to deeper waters. In biogeochemical models of oceanic carbon flux, a constant $\mathrm{C}: \mathrm{P}$ ratio is commonly used to estimate particulate organic carbon production in the surface layer from phosphate concentrations (e.g., Six and Maier-Reimer, 1996). Variable C: $P$ ratios would alter the strength of the soft-tissue pump. As an example, Heinze et al. (1991) demonstrated that a $30 \%$ global increase in $\mathrm{C}: \mathrm{P}$ could explain most 
of the $80 \mu \mathrm{atm}$ reduction of atmospheric $\mathrm{pCO}_{2}$ during the last glaciation.

A constant elemental proportionality in the utilization of primary nutrients by marine plankton during synthesis and in the subsequent remineralization of organic matter was first suggested by Redfield (1934). The "Redfield ratio" of C: $\mathrm{P}=$ 106: 1 (by atoms, Redfield et al., 1963) represents an average value for the elemental composition of marine phytoplankton $(108: 1)$ and zooplankton $(103: 1)$. Since the chemical composition is likely to differ between species, and species composition is variable in both time and space, Redfield et al. (1963) concluded that "statistical uniformity in composition is probably approached only in large masses of water, where deviations of this sort are averaged out". In marine phytoplankton, elemental ratios of a given species also vary with environmental conditions such as nutrient availability. Large deviations from the Redfield ratio, for example, occur upon N-limited or P-limited growth in chemostats (Perry, 1976; Sakshaug and Holm-Hansen, 1977).

High ambient concentrations of DIC relative to $\mathrm{N}$ and $\mathrm{P}$ led Redfield et al. (1963) to conclude that carbon was not limiting phytoplankton growth in the ocean. Even when gradients in nutrient concentrations between the bulk medium and the boundary layer of an algal cell are considered, diffusive supply of $\mathrm{CO}_{2}$ appears to meet cellular carbon demand in most cases (WolfGladrow and Riebesell, 1997), as was outlined in the previous section. Nevertheless, variable $\left[\mathrm{CO}_{2}\right]$ has been demonstrated to affect not only growth rate (see above) but also elemental composition of an algal cell. In batch culture experiments with two strains of the marine diatom Skeletonema costatum, Burkhardt and Riebesell (1997) observed variation of $\mathrm{C}: \mathrm{P}$ with $\left[\mathrm{CO}_{2}\right]$ (Fig. 4). Minimum $\mathrm{C}: \mathrm{P}$ ratios were only 41 to $55 \%$ of maximum values over the range of $\mathrm{CO}_{2}$ concentrations $\left(<2 \mathrm{mmol} \mathrm{m}^{-3}\right.$ to $\left.>30 \mathrm{~mol} \mathrm{~m}^{-3}\right)$ tested.

$\mathrm{CO}_{2}$-dependent changes in $\mathrm{C}: \mathrm{P}$ of the same magnitude and in the same direction were also observed for the marine diatoms Coscinodiscus wailesii and Asterionella glacialis (Fig. 4; Burkhardt et al., in press). This correlation of $\mathrm{C}: \mathrm{P}$ with $\left[\mathrm{CO}_{2}\right]$ indicates that systematic changes in plankton stoichiometry might occur in response to the currently observed, rapid increase in atmospheric $p \mathrm{CO}_{2}$. Elevated $\mathrm{C}: \mathrm{P}$ ratios at high concen-

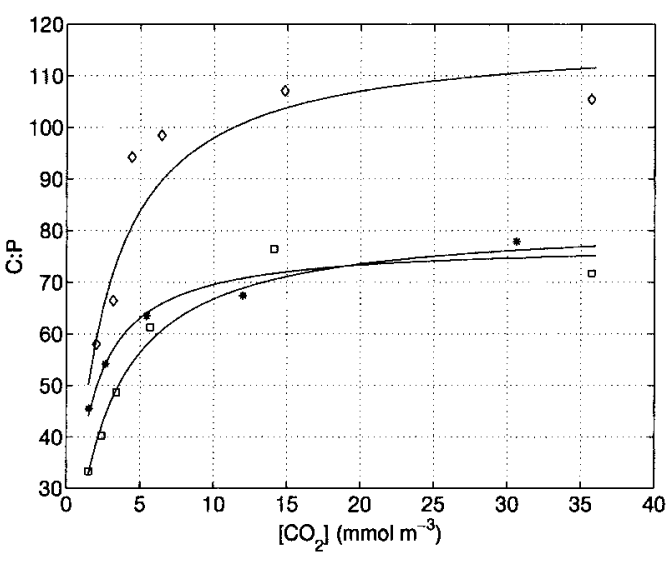

Fig. 4. The organic matter elementary composition (C:P) in marine diatoms Seile tonema costatum (*), Asterionella glacialis $(\diamond)$ and Coscinodiscus wailesii $(\square)$ as a function of $\left[\mathrm{CO}_{2}\right]$ in the medium (Burkhardt and Riebesell, 1997; Burkhardt et al., in press).

trations of carbon dioxide would enhance the strength of the soft-tissue pump by increasing the amount of carbon fixed per unit phosphate and ultimately the carbon flux from the euphotic zone to deeper waters. However, the $\mathrm{CO}_{2}$ concentration at which $\mathrm{C}: \mathrm{P}$ approaches an upper limit in the diatom species investigated so far (between 5 and $10 \mathrm{mmol} \mathrm{m}^{-3}$ ) is low and may not lead to an appreciable increase in carbon fixation under currently rising $\mathrm{CO}_{2}$ concentrations. On the other hand, it needs to be considered that even within one algal strain, cells might respond differently to variation in $\mathrm{CO}_{2}$ concentration depending on the time they have to acclimate to ambient conditions. In contrast to pre-adapted laboratory cultures, phytoplankton cells experience a rapid decline in $\left[\mathrm{CO}_{2}\right]$ during bloom development and might then show a larger response with respect to their elemental composition.

In spite of open questions, the observation of variable phytoplankton stoichiometry in response to $\mathrm{CO}_{2}$ supply challenges the commonly accepted notion of a $\mathrm{CO}_{2}$-independent Redfield ratio. Its relevance in the light of the current increase in $\mathrm{CO}_{2}$ concentrations remains to be resolved. Because of the regional and seasonal heterogeneity of plankton stoichiometry it is unlikely that a basin-wide systematic trend in the elemental composition of marine phytoplankton could be detected by direct measurements of sedimented 
particulate organic matter. On the other hand, long-term global trends in the Redfield ratio should be reflected in nutrient gradients in oceanic deep water.

3.1.3. Calcification. Increasing atmospheric $\mathrm{CO}_{2}$ concentrations will lead to lower $\mathrm{CO}_{3}^{2-}$ concentrations in ocean surface waters (Fig. 1). Accordingly, the degree of oversaturation with respect to calcite and aragonite will decrease. This may have two consequences. First, $\mathrm{CaCO}_{3}$ in sediments, especially the $\mathrm{Mg}^{2+}$ rich calcites in shelf regions, could dissolve (Wollast, 1994). Second, the rate of $\mathrm{CaCO}_{3}$ production could decrease. Almost all $\mathrm{CaCO}_{3}$ in the oceans is precipitated by organisms. The only exceptions are minor abiotic precipitations ("whitings") observed in the Persian Gulf (Morse and He, 1993). The response of calcifying marine organisms to changing carbonate concentrations has not yet been investigated in any detail. One can expect that the response depends on the carbon source used for calcification as well as the kind of mineral precipitated (aragonite, calcite, and the fraction of $\mathrm{MgCO}_{3}$ ).

For coccolithophorids $\mathrm{HCO}_{3}^{-}$has been suggested to be the carbon source used in calcification (Sikes and Wilbur, 1982). Since $\mathrm{HCO}_{3}^{-}$concentrations remain more or less constant with $\mathrm{CO}_{2}^{-}$ related changes in the carbonate system of the magnitude discussed here, calcification in coccolithophorids should be unaffected by these changes. In recent laboratory experiments with the coccolithophorid Emiliania huxleyi, however, the rate of calcification was found to decrease by ca. $40 \%$ with $\mathrm{CO}_{2}$ increasing from 5 to $35 \mathrm{mmol} \mathrm{m}^{-3}$ (Zondervan, personal communication). Over this $\mathrm{CO}_{2}$ range the rate of organic matter production remained more or less constant. Since increasing $\mathrm{CO}_{2}$ in these experiments was associated with a corresponding decrease in $\mathrm{pH}$ and in the $\mathrm{CO}_{3}^{2-}$ concentration, it is not possible to distinguish which of these factors ultimately caused calcification to subside. Nevertheless, as changes in $\left[\mathrm{CO}_{2}\right]$, $\mathrm{pH}$, and $\left[\mathrm{CO}_{3}^{2-}\right]$ also go hand in hand under natural conditions, the observed $\mathrm{CO}_{2}$-related effect on the rate of calcite production by E. huxleyi is directly applicable to the natural environment.

Orbulina universa, a planktonic foraminifer, most probably uses $\mathrm{CO}_{3}^{2-}$ as substrate for shell formation. Laboratory experiments under controlled conditions show that the shell weight decreases at $\mathrm{CO}_{3}^{2-}$ concentrations below $150 \mathrm{mmol} \mathrm{m}^{-3}$ (Fig. 5; Bijma et al., in press). Experimental results obtained by Langdon et al. (1997) and Gattuso et al. (1998) imply that a doubling of atmospheric $\mathrm{CO}_{2}$ will result in a $10-20 \%$ reduction in coral and reef calcification. To the best of our knowledge the response of pteropods, the most important aragonite forming organisms for the open ocean, has not been investigated.

Reduced $\mathrm{CaCO}_{3}$ production or increased dissolution of carbonates in shelf sediments leads to higher alkalinity in surface waters. The mean difference in alkalinity (normalized to a constant salinity of 35) between the surface ocean and the deep ocean is of the order of 100 mequiv $\mathrm{m}^{-3}$ (for example, Volk and Hoffert (1985), Sabine et al. (1995) measured a difference of 150 mequiv $\mathrm{m}^{-3}$ between the surface and $1000 \mathrm{~m}$ at the Hawaii Ocean Time series station). In order to estimate the potential impact of decreasing calcification rates on atmospheric $\mathrm{CO}_{2}$ levels the change in $p \mathrm{CO}_{2}$ due to a shutdown of the calcium carbonate pump has been calculated for a preindustrial situation. When the $\mathrm{CaCO}_{3}$ pump is shut down, the vertical alkalinity gradient in the upper 500 to $1000 \mathrm{~m}$ will almost vanish (for the influence of minor components such as nitrate on alkalinity see, for example, Brewer and Goldman, 1976) and surface water alkalinity will attain the deep ocean value. For $\mathrm{DIC}=2000 \mathrm{mmol} \mathrm{m}^{-3}$ and $\mathrm{TA}=$ 2300 mequiv $\mathrm{m}^{-3}$ a $p \mathrm{CO}_{2}=279 \mu \mathrm{atm}$ is obtained

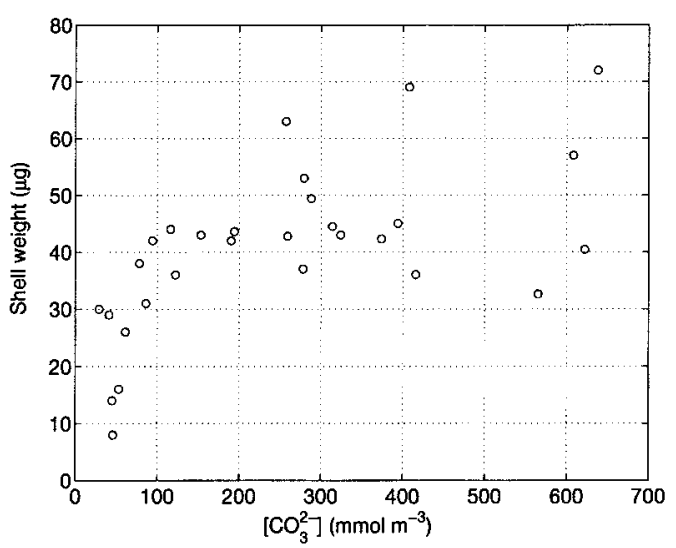

Fig. 5. The weight of $\mathrm{CaCO}_{3}$ shells of Orbulina universa grown in a $12 \mathrm{~h}: 12 \mathrm{~h}$ light-dark cycle as a function of $\mathrm{CO}_{3}^{2-}$-concentration (data from Bijma et al., 1998). 
at $T=15^{\circ} \mathrm{C}$ and $S=35$. When TA and DIC are increased by 100 mequiv $\mathrm{m}^{-3}$ and by $50 \mathrm{mmol} \mathrm{m}^{-3}$, respectively, $p \mathrm{CO}_{2}$ drops by almost $40 \mu \mathrm{atm}$. This back-of-an-envelope estimate is confirmed by a numerical experiment (Wischmeyer, personal communication) using the global carbon cycle model of Six and Maier-Reimer (1996). It is currently not known how marine $\mathrm{CaCO}_{3}$ production is distributed among foraminifera, pteropods, coccolithophorids and corals (Milliman and Droxler, 1996; Holligan and Robertson, 1996) and how different groups of organisms are affected by lower $\mathrm{CO}_{3}^{2-}$ concentrations. Thus, a quantification of possible changes in $\mathrm{CaCO}_{3}$ production and dissolution and their effect on the marine carbon cycle is presently not possible.

\subsection{Direct effects as diagnostic tools}

3.2.1. Carbon isotope fractionation in marine phytoplankton. The carbon isotopic composition $\left(\delta^{13} \mathrm{C}\right)$ of marine photosynthetic organisms can potentially provide important insights into the environmental conditions under which the organisms grew. Photosynthetic carbon isotope fractionation $\left(\varepsilon_{\mathrm{p}} \approx \delta^{13} \mathrm{C}_{\mathrm{CO}_{2}}-\delta^{13} \mathrm{C}_{\mathrm{POC}}\right.$; please note that some authors define $\varepsilon_{\mathrm{p}}$ with respect to $\delta^{13} \mathrm{C}_{\mathrm{DIC}}$ instead of $\delta^{13} \mathrm{C}_{\mathrm{CO}_{2}}$ ) is thought to be a function of the ratio of carbon demand to carbon supply. A low demand (i.e., low growth rate, $\mu$ ) and a high supply (e.g., high $\mathrm{CO}_{2}$ concentration) favors high fractionation and vice versa. Based on theoretical considerations, an inverse linear relationship between $\varepsilon_{\mathrm{p}}$ and $\mu /\left[\mathrm{CO}_{2}\right]$ is predicted in cases where diffusive $\mathrm{CO}_{2}$ uptake is the dominant pathway of carbon acquisition (Laws et al., 1995; Rau et al. 1996). Such a relationship — if applicable to common marine phytoplankton - raises the possibility of reconstructing past $\mathrm{CO}_{2}$ concentrations in the surface ocean from carbon isotope compositions of bulk organic matter or specific biomarkers in sedimentary material (Jasper and Hayes, 1990) and of estimating in situ phytoplankton growth rates from $\varepsilon_{\mathrm{p}}$ and $\left[\mathrm{CO}_{2}\right]$ measurements (Laws et al., 1995).

A relationship between $\left[\mathrm{CO}_{2}\right]$ and the carbon isotopic composition of marine phytoplankton has first been suggested by Degens et al. (1968) and has recently been confirmed in studies using monospecific marine phytoplankton cultures (e.g., Hinga et al., 1994; Laws et al., 1995 and 1997).
Significant correlations between $\left[\mathrm{CO}_{2}\right]$ and $\delta^{13} \mathrm{C}$ were also found for particulate organic matter (POM) in oceanic surface waters (e.g., Rau et al., 1989; Freeman and Hayes, 1992; Rau et al., 1992; Francois et al., 1993). However, as discussed by Goericke and Fry (1994), a large residual variance in surface ocean $\delta^{13} \mathrm{C}_{\mathrm{POM}}$ versus $\left[\mathrm{CO}_{2}\right]$ relationships suggests that factors other than $\left[\mathrm{CO}_{2}\right]$ also affect carbon isotope fractionation in natural populations.

The importance of cellular carbon demand on isotope fractionation, as suggested by Rau et al. (1992) and Francois et al. (1993), became evident in experiments by Laws et al. (1995), who obtained a linear relationship between $\varepsilon_{\mathrm{p}}$ and $\mu /\left[\mathrm{CO}_{2}\right]$. This observation was consistent with $\mathrm{CO}_{2}$ being the dominant carbon source and entering the cell via diffusive transport. Assuming diffusive $\mathrm{CO}_{2}$ uptake, Rau et al. (1996) developed a model predicting isotope fractionation as a function of various environmental and biological variables, such as $\mathrm{CO}_{2}$ concentration, temperature, salinity, $\mathrm{pH}$, growth rate, cell size, and cell membrane permeability. Although comparison of model predictions to existing experimental (Rau et al., 1996) and field data (Rau et al., 1997) appeared to substantiate some of the model predictions, data on isotope fractionation obtained under well-constrained conditions presently available are insufficient to rigorously test all aspects of the model.

Most recently, deviations from the predicted linear relationship between $\varepsilon_{\mathrm{p}}$ and $\mu /\left[\mathrm{CO}_{2}\right]$ were obtained in experiments in which the range of $\mathrm{CO}_{2}$ concentrations has been extended to well below $5 \mathrm{mmol} \mathrm{m}^{-3}$, concentrations generally not encountered in marine pelagic systems (Laws et al., 1997). This finding led Laws et al. (1997) to propose a non-linear relationship between $\varepsilon_{\mathrm{p}}$ and $\mu /\left[\mathrm{CO}_{2}\right]$ over the entire range of $\mathrm{CO}_{2}$ concentrations. A further complication resulted from observations of light-dependent differences in $\varepsilon_{\mathrm{p}}$ versus $\mu /\left[\mathrm{CO}_{2}\right]$ relationships (Riebesell, unpublished data). Under otherwise identical conditions, growth rate-normalized isotope fractionation was higher at higher light intensities. In addition, differences in $\mu /\left[\mathrm{CO}_{2}\right]$ responses in isotope fractionation were also obtained between different groups of marine phytoplankton (Popp et al., 1998). These findings suggest the importance of variables presently not constrained in the experi- 
ments or of factors not accounted for in the models of isotope fractionation.

Some of the gaps in our understanding of photosynthetic carbon isotope fractionation relate to uncertainties regarding the specific mechanisms of inorganic carbon acquisition and fixation. As discussed in the previous section, uncertainties with respect to carbon acquisition pathways concern the source(s) of inorganic carbon used by marine phytoplankton $\left(\mathrm{CO}_{2}\right.$ and $\mathrm{HCO}_{3}^{-}$differ in their isotopic signal by approximately $10 \%$ ), the operation and regulation of a carbon uptake mechanism, the cell membrane permeability to $\mathrm{CO}_{2}$, and the ratio of carbon uptake by the cell to carbon leakage out of the cell. Uncertainties regarding carbon fixation concern the contribution by $\beta$-carboxylases, the form of RUBISCO (form I or II) and its fractionation factor in various algal groups. Until we have a more complete understanding of carbon acquisition and fixation pathways, it will remain difficult to adequately interpret carbon isotope data or to make quantitative predictions of carbon isotope fractionation in phytoplankton.

3.2.2. Isotopic composition of calcite shells of foraminifera. Stable oxygen $\left(\delta^{18} \mathrm{O}\right)$ and carbon $\left(\delta^{13} \mathrm{C}\right)$ isotope measurements on foraminiferal calcite are routinely used for reconstructing paleoceanographic and paleoclimatic change. Shell $\delta^{18} \mathrm{O}$ values are a function of $\delta^{18} \mathrm{O}_{\mathrm{H}_{2} \mathrm{O}}$ and the calcification temperature, whereas shell $\delta^{13} \mathrm{C}$ values reflect $\delta^{13} \mathrm{C}_{\text {DIC }}$. These proxies have been used as a tool to reconstruct surface and deep water temperatures (Broecker, 1986; Labeyrie et al., 1987), glacial ice volumes (Shackleton and Opdyke, 1973), ocean circulation changes (Duplessy et al., 1988), and glacial-interglacial transfer between the terrestrial and oceanic carbon pools (Shackleton, 1977). Recently stable boron isotopes $\left(\delta^{11} \mathrm{~B}\right)$ were introduced as a tracer for estimating glacial to interglacial changes in $\mathrm{pH}$ (Sanyal et al., 1995, 1996).

$\delta^{13} C$. The $\delta^{13} \mathrm{C}_{\text {DIC }}$ in surface waters increases when organic material is formed by microalgae which discriminate against ${ }^{13} \mathrm{C}$ with a fractionation factor on the order of 20\% (compare Subsection 3.2.1). While settling to the ocean floor part of this isotopically light material is remineralized, and thereby decreases the $\delta^{13} \mathrm{C}_{\text {DIC }}$ of deeper waters. The difference of $\delta^{13} \mathrm{C}_{\mathrm{DIC}}$ between surface and bottom thus varies with the amount of biological production. Consequently, if $\delta^{13} \mathrm{C}$ of foraminiferal shells reflects $\delta^{13} \mathrm{C}$ of DIC, the difference between benthic and planktonic foraminifera can be used as a proxy for biological production. However, already the pioneers of foraminiferal $\delta^{13} \mathrm{C}$ (Duplessy et al., 1970; Shackleton, 1977; Berger, 1979; Kahn, 1979) observed that the carbon isotopic composition of the shells, $\delta^{13} \mathrm{C}_{\mathrm{s}}$, does not necessarily precisely reflect the isotopic composition of the dissolved inorganic carbon, $\delta^{13} \mathrm{C}_{\text {DIC }}$. The species-specific and ontogenetic differences were attributed to (unspecified) "vital effects". Using culture experiments, Spero and coworkers were the first to document the substantial impact of the symbionts on shell $\delta^{13} \mathrm{C}$ (Spero and DeNiro, 1987; Spero, 1992) and the minor effect of host respiration (Spero and Lea, 1996). When applying $\delta^{13} \mathrm{C}$ to the fossil record, the studies published to date assume that in addition to a shell-size dependent offset (Berger et al., 1978) the $\delta^{13} \mathrm{C}_{\text {DIC }}$ can be derived from $\delta^{13} \mathrm{C}_{\mathrm{s}}$ plus a constant offset due to "vital effects" (Shackleton and Vincent, 1978).

The global mean value of $\delta^{13} \mathrm{C}_{\mathrm{DIC}}$ changes when isotopically light carbon from land biota $\left(\delta^{13} \mathrm{C}_{\text {land biota }} \approx-25 \%\right.$ ) $)$ is deposited into the oceans. A compilation by Curry et al. (1988) suggests that mean ocean $\delta^{13} \mathrm{C}$ was $0.4 \%$ more negative during the last glacial maximum. A 30\% reduction of the present biospheric carbon reservoir (equivalent to $600 \mathrm{Gt}$ carbon) is required to explain this shift by a transfer of carbon from the terrestrial biosphere to the oceans (Shackleton, 1977; Crowley, 1995).

However, laboratory experiments with living foraminifera under conditions of controlled $\mathrm{CO}_{2}$ and alkalinity have shown that the carbon isotopic composition of the shells strongly depends on the chemical state of the carbonate system. Spero et al. (1997) and Bijma et al. (in press) demonstrated that the shells become isotopically lighter at higher $\mathrm{CO}_{3}^{2-}$ concentrations (Fig. 6). This finding provides an alternative hypothesis to the terrestrial biosphere-to-ocean transfer of carbon that has been put forward as an explanation for lower glacial shell $\delta^{13} \mathrm{C}$ values. The 0.2 units higher $\mathrm{pH}$ of glacial surface waters, calculated by Sanyal et al. (1995) on the basis of boron isotopes, are evidence for a significantly higher carbonate ion concentration during the glacial. Calculations by 


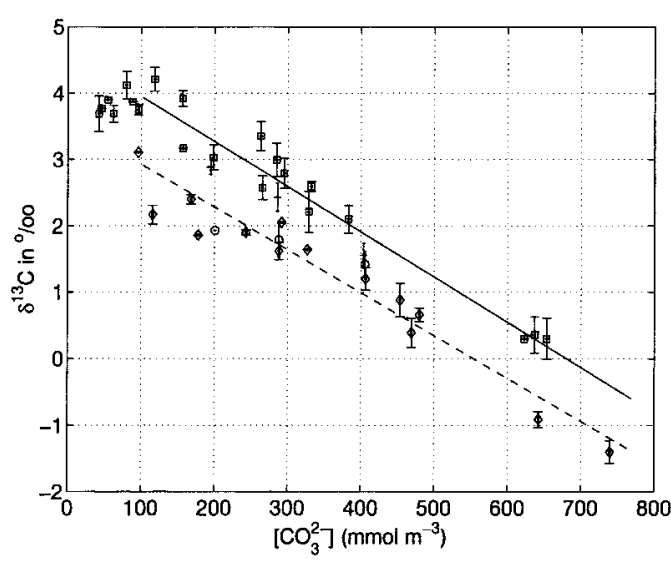

Fig. 6. Carbon isotopic composition, $\delta^{13} \mathrm{C}$, of calcite shells of Orbulina universa as a function of $\mathrm{CO}_{3}^{2-}$ concentration (at constant alkalinity $=$ ca. 2800 mequiv $\mathrm{m}^{-3}$ ). Specimens were kept in a $12 \mathrm{~h}: 12 \mathrm{~h}$ light-dark cycle $(\diamond$ at $22^{\circ} \mathrm{C}$; $\bigcirc$ at $17^{\circ} \mathrm{C}$ ) or in darkness $\left(\square\right.$ at $22^{\circ} \mathrm{C}$; + at $17^{\circ} \mathrm{C}$ ); data from Spero et al., 1997, and Bijma et al., in press.

Lea et al. (in press) show that to achieve equilibrium with a glacial atmospheric $p \mathrm{CO}_{2}$ of $200 \mu \mathrm{atm}$, surface water $\left[\mathrm{CO}_{3}^{2-}\right]$ must have increased by a minimum of $40 \mathrm{mmol} \mathrm{m}^{-3}$. Combining this conservative estimate with the experimental relationships suggests that the glacial rise in $\left[\mathrm{CO}_{3}^{2-}\right]$ can account for at least a 0.25 to $0.5 \%$ drop in shell $\delta^{13} \mathrm{C}$ (depending on the species-specific response). However, depending on sea surface temperature and the actual mode of $p \mathrm{CO}_{2}$ change, considerably larger changes are possible (Lea et al., in press). If part of the negative interglacial to glacial carbon isotope shift that is common to all species can be attributed to a $\left[\mathrm{CO}_{3}^{2-}\right]$ increase, this reduces the inferred glacial-interglacial shift in mean ocean $\delta^{13} \mathrm{C}_{\text {DIC }}$.

This new discovery also provides a novel explanation for the large, negative excursions in planktonic $\delta^{13} \mathrm{C}$ observed in the glacial sections of southern ocean cores (Lea et al., in press) and confounds the interpretation of planktonic-benthic $\delta^{13} \mathrm{C}$ differences $\left(\Delta \delta^{13} \mathrm{C}\right)$ as a measure of the efficiency of the biological production (Shackleton et al., 1983). Because a $0.1 \%$ increase in $\delta^{13} \mathrm{C}$ translates to an approximate $10 \mu \mathrm{atm}$ drop in $p \mathrm{CO}_{2}$, a $0.25 \%$ correction on planktonic foraminifera, which is the minimum calculated, can explain an additional $25 \mu \mathrm{atm}$ glacial-interglacial $p \mathrm{CO}_{2}$ difference, implying a stronger glacial biological pump than previously indicated (Shackleton et al., 1992). However, this calculation does not take into account a potential $\left[\mathrm{CO}_{3}^{2-}\right]$ influence on benthic shell $\delta^{13} \mathrm{C}$ and depends on species-specific responses to $\left[\mathrm{CO}_{3}^{2-}\right]$ for which experimental data are not available.

The variation of the carbon isotopic composition in $O$. universa under varying conditions of the carbonate system can be explained to a large degree by a reaction-diffusion model for the physiological micro-environment which takes into account respiration, calcification and photosynthesis by the symbionts (Wolf-Gladrow et al., 1999; Zeebe et al., 1999).

$\delta^{18} O$. Urey (1947) showed, from first principles, that the temperature at which calcium carbonate precipitates from a solution affects the ratio of the stable oxygen isotopes in the precipitate. In thermodynamic equilibrium, calcite and seawater differ in their ${ }^{18} \mathrm{O} /{ }^{16} \mathrm{O}$ ratios, and the difference decreases with increasing temperature. $\mathrm{He}$ proposed therefore that the $\delta^{18} \mathrm{O}$ value of carbonate from the geologic record contains a paleotemperature signal. Foraminiferal shells precipitated in equilibrium are enriched in ${ }^{18} \mathrm{O}$ relative to seawater but less so with increasing temperature. As for $\delta^{13} \mathrm{C}$, data from isotopic calibration studies suggested that a previously unidentified parameter also affects the oxygen isotope ratios in foraminiferal shells (Fairbanks et al., 1982; Spero and Lea, 1996). While observations of $\delta{ }^{13} \mathrm{C}$-disequilibrium precipitation can be attributed to respiration or symbiont photosynthesis, shell $\delta^{18} \mathrm{O}$ values should be insensitive to physiology. McCrea (1950) showed that $\delta^{18} \mathrm{O}$ of inorganically precipitating calcite became depleted in ${ }^{18} \mathrm{O}$ as the carbonate ion concentration in the solution was increased. Spero et al. (1997) and Bijma et al. (in press) also find that $\delta^{18} \mathrm{O}$ varies with $\mathrm{CO}_{3}^{2-}$ concentration (Fig. 7). The slope $\mathrm{d} \delta^{18} \mathrm{O} / \mathrm{d}\left[\mathrm{CO}_{3}^{2-}\right]$ differs by a factor of 2 between the two species $O$. univers $a$ and $G$. bulloides. Interestingly the slope $\mathrm{d} \delta^{18} \mathrm{O} / \mathrm{d} \delta^{13} \mathrm{C}$ is almost the same for both species and for the non-symbiotic coral Tubastrea sp., indicating that a similar mechanism is responsible for the observed variations.

Anomalies in $\delta^{18} \mathrm{O}$ computed for an $80 \mu \mathrm{atm}$ $p \mathrm{CO}_{2}$ reduction, range from -0.1 to $-0.3 \%$, equivalent to a sea surface temperature (SST) 


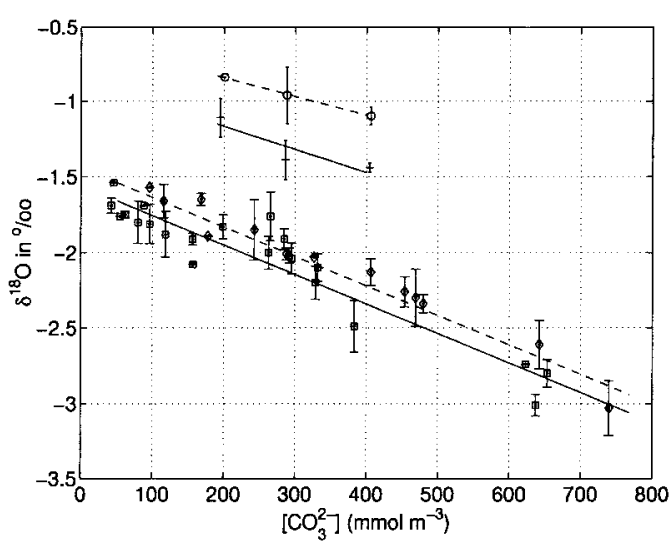

Fig. 7. Oxygen isotopic composition, $\delta^{18} \mathrm{O}$, of calcite shells of Orbulina universa as a function of $\mathrm{CO}_{3}^{2-}$ concentration (at constant alkalinity $=\mathrm{ca} .2800$ mequiv $\mathrm{m}^{-3}$ ). Specimens were kept in a $12 \mathrm{~h}: 12 \mathrm{~h}$ light-dark cycle $\left(\diamond\right.$ at $22^{\circ} \mathrm{C}$; $\bigcirc$ at $\left.17^{\circ} \mathrm{C}\right)$ or in darkness $\left(\square\right.$ at $22^{\circ} \mathrm{C}$; + at $17^{\circ} \mathrm{C}$ ); data from Spero et al. (1997) and Bijma et al., in press.

anomaly of approximately -0.5 to $-1.5^{\circ} \mathrm{C}$ (Lea et al., in press). These anomalies in shell $\delta^{18} \mathrm{O}$ translate into overestimates of paleotemperature during periods of low $p \mathrm{CO}_{2}$ and thus bring oxygen isotope paleotemperatures closer to other marine SST proxies (e.g. coral $\mathrm{Sr} / \mathrm{Ca}$ ) and terrestrial indicators (e.g., snow-line and ice core $\delta^{18} \mathrm{O}$ ) that suggest more intense tropical cooling at the last glacial maximum (Guilderson et al., 1994; Thompson et al., 1995).

$\delta^{11} B$. Hemming and Hanson (1992; see also Vengosh et al., 1991) found that the boron isotopic composition $\delta^{11} \mathrm{~B}$ in modern marine carbonates varies with $\mathrm{pH}$. The isotopic composition of the two forms of borate, $\mathrm{B}(\mathrm{OH})_{3}$ and $\mathrm{B}(\mathrm{OH})_{4}^{-}$, differ by $20 \%$ and both vary with $\mathrm{pH}$. Under the assumption that only the charged species $\left(\mathrm{B}(\mathrm{OH})_{4}^{-}\right)$is incorporated with a constant fractionation $(0.8 \%)$ into the shell the observations can be explained. Sanyal et al. (1995) calculated from boron isotope data that the $\mathrm{pH}$ of surface water of glacial age in the tropical Atlantic and Pacific oceans was $0.2( \pm 0.1) \mathrm{pH}$ units higher than that during the Holocene, and that the $\mathrm{pH}$ of glacial deep water in the equatorial Atlantic and Pacific oceans was $0.3( \pm 0.1) \mathrm{pH}$ units higher than during the Holocene.

\section{Summary}

The limited information presently available on direct effects of $\mathrm{CO}_{2}$-related changes in seawater chemistry on the marine biota is largely based on laboratory experiments. Until more field data become available extrapolation of these results to the natural environment remains hypothetical. Clearly, rising $\mathrm{CO}_{2}$ concentrations will favor algal species with high carbon demand and a low surface area to volume ratio as well as species lacking a carbon concentrating mechanism. Thus, a shift in phytoplankton community structure towards larger cell sizes may occur in bottom-up controlled plankton communities. However, reliable predictions of future developments in plankton species composition are impossible as long as we are unable to fully understand the factors controlling composition and succession of present day plankton communities.

$\mathrm{CO}_{2}$-dependent responses of marine phytoplankton with regard to growth rate, elemental composition, and isotope fractionation are all reflections of the cell's nutritional status with respect to inorganic carbon. Thus, although a mechanistic explanation for the observed co-variation is still lacking, linkages between these responses are to be expected. Observations of changes in one factor may therefore be indicative for changes in the others. Recent findings of increased carbon isotope values in newly produced suspended and sedimented organic matter relative to material originating from preindustrial times (Bentaleb et al., 1996; Bentaleb and Fontugne, 1996; Fischer et al., 1997; Bentaleb et al., 1998; Fischer et al., 1998) suggest, that the increase in surface ocean $\mathrm{CO}_{2}$ concentrations over the past century has affected carbon metabolism of natural marine phytoplankton. Whatever the corresponding effect on growth rate and elemental composition may be, it should not automatically be assumed that the ocean's biological carbon pumps are irresponsive to changes in atmospheric $\mathrm{CO}_{2}$. Enhanced growth rates and increasing $\mathrm{C}: \mathrm{P}$ ratios of marine phytoplankton in response to rising $\mathrm{CO}_{2}$ concentrations would strengthen the soft tissue pump. Reduced biogenic calcification, on the other hand, would weaken the $\mathrm{CaCO}_{3}$ counter pump. Thus, all three effects would raise the ocean's capacity to store atmospheric $\mathrm{CO}_{2}$ 
and hence represent negative feedbacks with respect to anthropogenic $\mathrm{CO}_{2}$ increase. In view of the potential importance of these processes we wish to emphasize that future modeling of the global ocean carbon cycle should include the possibility of $\mathrm{CO}_{2}$-sensitive biological carbon pumps.

\section{Acknowledgements}

We thank Andrew Watson and Michel Fontugne for critical comments. This is publication number 1449 of the Alfred Wegener Institute for Polar and Marine Research.

\section{REFERENCES}

Bentaleb, I. and Fontugne, M. 1996. Anthropogenic $\mathrm{CO}_{2}$ invasion of the surface ocean: its influence on the organic carbon isotope composition of phytoplankton. C.R. Acad. Sci. Paris t. 322, Série II a: 743-748.

Bentaleb, I., Fontugne, M.,Descolas-Gros, C., Girardin, C., Mariotti, A., Pierre, C., Brunet, C. and Poisson, A. 1996. Organic carbon isotopic composition of phytoplankton and sea-surface $p \mathrm{CO}_{2}$ reconstructions in the southern Indian Ocean during the last $50000 \mathrm{yr}$ Organic Geochemistry 24, 399-410.

Bentaleb, I., Fontugne, M., Descolas-Gros, C., Girardin, C., Mariotti, A., Pierre, C., Brunet, C. and Poisson, A. 1998. Carbon isotope fractionation by plankton in the southern Indian Ocean: relationship between $\delta{ }^{13} \mathrm{C}$ of particulate organic carbon and dissolved carbon dioxide. J. Mar. Sys. 17, 39-58.

Berger, W. H. 1979. Stable isotopes in foraminifera. In: Foraminiferal ecology and paleoecology (eds. Lipps, J. H., Berger, W. H., Buzas, M. A., Douglas, R. G. and Ross, C. A) (SEPM Short Course no. 6), pp. 156-197. Society of Economic Paleontologists and Mineralogists.

Berger, W. H., Killingly, J. S. and Vincent, E. 1978. Stable isotopes in deep-sea carbonates: Box core ERDC-92, west equatorial Pacific. Oceanol. Acta 1, 203-216.

Bijma, J., Spero, H. J., Lea, D. W. and Bemis, B. E. (in press). Reassessing foraminiferal stable isotopes: Effects of seawater carbonate chemistry (experimental results). In: Proxies in Paleoceanography (eds. Fischer, G. and Wefer, G). Springer.

Brewer, P. G. and Goldman, J. C. 1976. Alkalinity changes generated by phytoplankton growth. Limnol. Oceanogr. 21, 108-117.

Brewer, P. G. 1997. Ocean chemistry of the fossil fuel $\mathrm{CO}_{2}$ signal: The haline signal of "business as usual". Geophys. Res. Lett. 24, 1367-1369.

Broecker, W. S. 1986. Oxygen isotope constraints on surface ocean temperatures. Quaternary Research 26 , 121-134.

Burkhardt, S. and Riebesell, U. 1997. $\mathrm{CO}_{2}$ availability affects elemental composition $(\mathrm{C}: \mathrm{N}: \mathrm{P})$ of the marine diatom Skeletonema costatum. Mar. Ecol. Prog. Ser. 155, 67-76.

Burkhardt, S., Zondervan, I. and Riebesell, U. 1999. Effect of $\mathrm{CO}_{2}$ concentration on the $\mathrm{C}: \mathrm{N}: \mathrm{P}$ ratio in marine phytoplankton. A species comparison. Limnol. Oceanogr., in press.
Burns, B. D. and Beardall, J. 1987. Utilization of inorganic carbon by marine microalgae. J. Exp. Mar. Biol. Ecol. 107, 75-86.

Chen, C. Y. and Durbin, E. G. 1994. Effects of $\mathrm{pH}$ on the growth and carbon uptake of marine phytoplankton. Mar. Ecol. Prog. Ser. 109, 83-94.

Codispoti, L. A., Friederich, G. E., Iverson, R. L. and Hood, D. W. 1982. Temporal changes in the inorganic carbon system of the south-eastern Bering Sea during spring 1980. Nature 296, 242-245.

Colman, B. and Rotatore, C. 1995. Photosynthetic inorganic carbon uptake and accumulation in two marine diatoms. Plant. Cell. Environ. 18, 919-924.

Cooper, T. G., Filmer, D., Wishnick, M. and Lane, M. D. 1969. The active species of " $\mathrm{CO}_{2}$ " utilized by ribulose diphosphate carboxylase. J. Biol. Chem. 244, 1081-1083.

Crowley, T. J. 1995. Ice age terrestrial carbon changes revisited. Global Biogeochem. Cycles 9, 377-389.

Curry, W. B., Duplessy, J. C., Labeyrie, L. D. and Shackleton, N. J. 1988. Changes in the distribution of $\delta^{13} \mathrm{C}$ of deep water $\Sigma \mathrm{CO}_{2}$ between the last glaciations and the Holocene. Paleoceanography 3, 317-342.

Degens, E. T., Guillard, R. R. L., Sackett, W. M. and Hellebust, J. A. 1968. Metabolic fractionation of carbon isotopes in marine plankton. I. Temperature and respiration experiments. Deep-Sea Res. 15, 1-9.

Dickson, A. G. 1981. An exact definition of total alkalinity and a procedure for the estimation of alkalinity and total inorganic carbon from titration data. DeepSea Res. 28A, 609-623.

Duplessy, J. C., Lalou, C. and Vinot-Bertouille, A. C. 1970. Differential isotopic fractionation in benthic foraminifera and paleotemperature, reassessed. Science 168, 250-251.

Duplessy, J. C., Shackleton, N. J., Fairbanks, R. G., Labeyrie, L., Oppo, D. and Kallel, N. 1988. Deepwater source variations during the last climatic cycle and their impact on the global deepwater circulation. Paleoceanography 3, 343-360.

Fairbanks, R. G., Sverdlove, M. S., Free, R., Wiebe, P. H. and Bé, A. W. H. 1982. Vertical distribution and isotopic fractionation of living planktonic foraminifera from the Panama basin. Nature 298, 841-844.

Falkowski, P. and Raven, J. 1996. Aquatic photosynthesis. Blackwell Science, p. 356.

Fischer, G., Müller, P. J. and Wefer, G. 1998. Latitudinal 
$\delta^{13} \mathrm{C}_{\mathrm{org}}$ variations in sinking matter and sediments from the South Atlantic: effects of anthropogenic $\mathrm{CO}_{2}$ and implications for palaeo- $\mathrm{PCO}_{2}$ reconstructions. J. Mar. Sys. 17, 471-495.

Fischer, G., Schneider, R., Müller, P. J. and Wefer, G. 1997. Anthropogenic $\mathrm{CO}_{2}$ in Southern Ocean surface waters: evidence from stable organic carbon isotopes. Terra Nova 9, 153-157.

Francois, R., Altabet, M. A., Goericke, R., McCorkle, D. C., Brunet, C. and Poisson, A. 1993. Changes in the $\delta^{13} \mathrm{C}$ of surface water particulate organic matter across the subtropical convergence in the SW Indian Ocean. Global Biogeochem. Cycles 7, 627-644.

Freemann, K. H. and Hayes, J. H. 1992. Fractionation of carbon isotopes by phytoplankton and estimates of ancient $\mathrm{CO}_{2}$ levels. Global Biogeochem. Cycles 6, $185-198$.

Gattuso, J.-P., Frankignoulle, M., Bourge, I., Romaine, S and Buddemeier, R. W. 1998. Effect of calcium carbonate saturation of seawater on coral calcification. Global and Planetary Change 18, 37-46.

Goericke, R. and Fry, B. 1994. Variations of marine plankton $\delta^{13} \mathrm{C}$ with latitude, temperature, and dissolved $\mathrm{CO}_{2}$ in the world ocean. Global Biogeochemical Cycles 8, 85-90.

Guilderson, T. P., Fairbanks, R. G. and Rubenstone, J. L. 1994. Tropical temperature variations since 20000 years ago: Modulating interhemispheric climate change. Science 263. 663-665.

Hasselmann, K., Hasselmann, S., Giering, R., Ocana, V. and von Storch, H. 1996. Optimization of $\mathrm{CO}_{2}$ emissions using coupled integral climate response and simplified cost models. A sensitivity study. Max-Planck-Institut für Meteorologie, Report No. 192.

Hein, M. and Sand-Jensen, K. 1997. $\mathrm{CO}_{2}$ increases oceanic primary production. Nature 388, 526-527.

Heinze, C., Maier-Reimer, E. and Winn, K. 1991. Glacial $p \mathrm{CO}_{2}$ reduction by the world ocean: Experiments with the Hamburg Carbon Cycle Model. Paleoceanography 6, 395-430.

Hemming, N. G. and Hanson, G. N. 1992. Boron isotopic composition and concentration in modern marine carbonates. Geochimica et Cosmochimica Acta 56, 537-543.

Hinga, K. R., Arthur, M. A., Pilson, M. E. Q. and Whitaker, D. 1994. Carbon isotope fractionation by marine phytoplankton in culture: The effects of $\mathrm{CO}_{2}$ concentration, $\mathrm{pH}$, temperature, and species. Global Biogeochem. Cycles 8, 91-102.

Holligan, P. M. and Robertson, J. E. 1996. Significance of ocean carbonate budgets for the global carbon cycle. Global Change Biology 2, 85-95.

IPCC. 1995. Climate change 1995. The science of climate change: contribution of Working group I to the $2 \mathrm{nd}$ assessment report of the Inter-governmental Panel on Climate change. Houghton, J. T., Meira Filho, L. G., Callander, B. A., Harris, N., Kattenberg, A. and Maskell, K. (eds.). Cambridge University Press, Cambridge, UK.
Jasper, J. P. and Hayes, J. M. 1990. A carbon isotope record of $\mathrm{CO}_{2}$ levels during the late Quaternary. Nature 347, 462-464.

Johnson, K. S. 1982. Carbon dioxide hydration and dehydration kinetics in seawater. Limnol. Oceanogr. 27, 849-855.

Kahn, M. I. 1979. Non-equilibrium oxygen and carbon isotope fractionation in tests of living planktonic foraminifera. Oceanol. Acta 2, 195-208.

Korb, R. E., Saville, P. J., Johnston, A. M. and Raven, J. A. 1997. Sources of inorganic carbon for photosynthesis by three species of marine diatoms. J. Phycol. 33, 433-440.

Labeyrie L. D., Duplessy, J. C. and Blanc, P. L. 1987. Variation in mode of formation and temperature of oceanic deep waters over the past 125000 years. Nature 327, 477-482.

Langdon, C., Takahashi, T., McConnaughey, T., Anderson, H. and West, H. 1997. Effect of calcium carbonate saturation state on the rate of calcification of an experimental coral reef [abstract]. Amer. Zool. 37, $72 \mathrm{~A}$.

Laws, E. A., Popp, B. N., Bidigare, R. R., Kennicutt, M. C. and Macko, S. A. 1995. Dependence of phytoplankton carbon isotopic composition on growth rate and $\left[\mathrm{CO}_{2}\right]_{\mathrm{aq}}$ : theoretical considerations and experimental results. Geochim. Cosmochim. Acta 59, 1131-1138.

Laws, E. A., Bidigare, R. R. and Popp, B. N. 1997. Effect of growth rate and $\mathrm{CO}_{2}$ concentration on carbon isotopic fractionation by the marine diatom Phaeodactylum tricornutum. Limnol. Oceanogr. 42, 1552-1560.

Lea, D. W., Bijma, J., Spero, H. J. and Archer, D. (in press). Implications of a carbonate ion effect on shell carbon and oxygen isotopes for glacial ocean conditions. In: Proxies in paleoceanography (eds. Fischer, G. and Wefer, G). Springer.

Maier-Reimer, E. 1993. Geochemical cycles in an ocean general circulation model. Preindustrial tracer distributions. Global Biogeochem. Cycles 7, 645-677.

Maier-Reimer, E. and Hasselmann, K. 1987. Transport and storage of $\mathrm{CO}_{2}$ in the ocean - an inorganic ocean-circulation carbon cycle model. Climatic Dynamics 2, 63-90.

Maier-Reimer, E., Mikolajewicz, U. and Winguth, A 1996. Future ocean uptake of $\mathrm{CO}_{2}$ : interaction between ocean circulation and biology. Climate Dynamics 12, 711-721.

McCrea, J. M. 1950. On the isotopic chemistry of carbonates and a paleotemperature scale. Journal of Chemical Physics 18, 849-857.

Milliman, J. D. and Droxler, A. W. 1996. Neritic and pelagic carbonate sedimentation in the marine environment: ignorance is not bliss. Geologische Rundschau 85, 496-504.

Morel, F. M. M., Reinfelder, J. R., Roberts, S. B., Chamberlain, C. P., Lee, J. G. and Yee, D. 1994. Zinc and carbon co-limitation of marine phytoplankton. Nature 369, 740-742. 
Morse, J. W. and He, S. 1993. Influences of T, S and $\mathrm{P}_{\mathrm{CO}_{2}}$ on the pseudo-homogeneous precipitation of $\mathrm{CaCO}_{3}$ from seawater: implications for whiting formation. Marine Chemistry 41, 291-297.

Perry, M. J. 1976. Phosphate utilization by an oceanic diatom in phosphorus-limited chemostat culture and in the oligotrophic waters of the central North Pacific Limnol. Oceanogr. 21, 88-107.

Popp, B. N., Dore, J. E., Bidigare, R. R., Laws, E. A., Hanson, K. L. and Wakeham, S. G. 1998. Effect of phytoplankton cell geometry on carbon isotopic fractionation. Geochimica et Cosmochimica Acta 62, 69-77.

Rau, G. H., Takahashi, T. and Des Marais, D. J. 1989. Latitudinal variations in plankton $\delta^{13} \mathrm{C}$ : implications for $\mathrm{CO}_{2}$ and productivity in past oceans. Nature 341, 516-518.

Rau, G. H., Takahashi, T., Des Marais, D. J., Repeta, D. J. and Martin, J. H. 1992. The relationship between $\delta^{13} \mathrm{C}$ of organic matter and $\left[\mathrm{CO}_{2}(\mathrm{aq})\right]$ in ocean surface water: Data from a JGOFS site in the northeast Atlantic Ocean and a model. Geochimica et Cosmochimica Acta 56, 1413-1419.

Rau, G. H., Riebesell, U. and Wolf-Gladrow, D. 1996. A model of photosynthetic ${ }^{13} \mathrm{C}$ fractionation by marine phytoplankton based on diffusive molecular $\mathrm{CO}_{2}$ uptake. Mar. Ecol. Prog. Ser. 133, 275-285.

Rau, G. H., Riebesell, U. and Wolf-Gladrow, D. 1997. $\mathrm{CO}_{2}$ (aq)-dependent photosynthetic ${ }^{13} \mathrm{C}$ fractionation in the ocean: A model versus observations. Global Biogeochem. Cycles 11, 267-278.

Raven, J. A. 1997. Inorganic carbon acquisition by marine autotrophs. Advances in Botanical Research 27, 85-209.

Redfield, A. C. 1934. On the proportions of organic derivatives in sea water and their relation to the composition of plankton. James Johnstone Memorial Volume, Liverpool, pp. 177-192.

Redfield, A. C., Ketchum, B. H. and Richards, F. A. 1963. The influence of organisms on the composition of seawater. In: The Sea 2 (ed. Hill, M. N.). Interscience, New York, pp. 1-34.

Riebesell, U., Wolf-Gladrow, D. and Smetacek, V. 1993 Carbon dioxide limitation of marine phytoplankton growth rates. Nature 361, 249-251.

Roberts, S. B., Lane, T. W. and Morel, F. M. M. 1997. Carbonic anhydrase in the marine diatom Thalassiosira weissflogii (bacillariophyceae). J. Phycol. 33, 845-850.

Robertson, J. E., Robinson, C., Turner, D. R., Holligan, P., Watson, A. J., Boyd, P., Fernandez,E. and Finch, M. 1994. The impact of a coccolithophore bloom on oceanic carbon uptake in the N.E. Atlantic during summer 1991. Deep-Sea Res. 41, 297-314.

Sabine, C. L., Mackenzie, F. T., Winn, C. and Karl, D. M. 1995. Geochemistry of carbon dioxide in seawater at the Hawaii Ocean Time series station, ALOHA. Global Biogeochem. Cycles 9, 637-651.

Sakshaug, E. and Holm-Hansen, O. 1977. Chemical composition of Skeletonema costatum (Grev.) Cleve and
Pavlova (Monochrysis) Lutheri (Droop) Green as a function of nitrate-, phosphate-, and iron-limited growth. J. Exp. Mar. Biol. Ecol. 29, 1-34.

Sanyal, A., Hemming, N. G., Hanson, G. N. and Broecker, W. S. 1995. Evidence for a higher $\mathrm{pH}$ in the glacial ocean from boron isotopes in foraminifera. Nature 373, 234-236.

Sanyal, A., Hemming, N. G., Broecker, W. S., Lea, D. W., Spero, H. J. and Hanson, G. N. 1996. Oceanic pH control on the boron isotopic composition of foraminifera: evidence from culture experiments. Paleoceanography 11, 513-517.

Sarmiento, J. L., Murnane, R. and Le Quéré, C. 1995. Air-sea $\mathrm{CO}_{2}$ transfer and the carbon budget of the North Atlantic. Philosophical Transactions: Biological Sciences, Series B 348, 211-219.

Shackleton, N. J. 1977. Carbon 13 in Uvigerina: Tropical rain forest history and the equatorial pacific carbonate dissolution cycles. In: The fate of fossil fuel $\mathrm{CO}_{2}$ in the oceans (eds. Anderson, N. R. and Malahoff, A.), pp. 401-427. Plenum, New York.

Shackleton, N. J. and Vincent, E. 1978. Oxygen and carbon isotope studies in recent foraminifera from the southwest Indian Ocean. Mar. Micropaleontol. 3, 1-13.

Shackleton, N. J. and Opdyke, N. D. 1973. Oxygen isotope and palaeomagnetic stratigraphy of equatorial Pacific core V28-238: oxygen isotope temperatures and ice volumes on a $10^{5}-10^{6}$ year scale. Quaternary Research 3, 39-55.

Shackleton N. J., Le, J., Mix, A. and Hall, M. A. 1992. Carbon isotope records from Pacific surface waters and atmospheric carbon dioxide. Quaternary Science Reviews 11, 387-400.

Shackleton, N. J., Hall, M. A., Line, J. and Shuxi, C. 1983. Carbon isotope data in core V19-30 confirm reduced carbon dioxide concentration of the ice age atmosphere. Nature 307, 620-623.

Sikes, C. S. and Wilbur, K. M. 1982. Functions of coccolith formation. Limnol. Oceanogr. 27, 18-26.

Six, K. D. and Maier-Reimer, E. 1996. Effects of plankton dynamics on seasonal carbon fluxes in an ocean general circulation model. Global Biogeochem. Cycles 10, $559-583$.

Spero, H. J. 1992. Do planktic foraminifera accurately record shifts in the carbon isotopic composition of seawater $\mathrm{CO}_{2}$ ? Mar. Micropaleontol. 19, 275-285.

Spero, H. J. and Lea, D. W. 1996. Experimental determination of stable isotope variability in Globigerina bulloides. Implications for paleoceanographic reconstructions. Mar. Micropaleontol. 28, 231-246.

Spero, H. J. and DeNiro, M. J. 1987. The influence of symbiont photosynthesis on the $\delta^{18} \mathrm{O}$ and $\delta^{13} \mathrm{C}$ values of planktonic foraminiferal shell calcite. Symbiosis $\mathbf{4}$, 213-228.

Spero, H. J., Bijma, J., Bemis, B. and Lea, D. W. 1997. Effect of seawater carbonate concentration on foraminiferal carbon and oxygen isotopes. Nature 390, 497-500.

Strain, B. R. and Cure, J. D. (eds.). 1994. Direct effects

Tellus 51B (1999), 2 
of atmospheric $\mathrm{CO}_{2}$ enrichment on plants and ecosystems: an updated bibliographic data base. Carbon Dioxide Information Analysis Center, Environmental Sciences Division, Oak Ridge National Laboratory, Oak Ridge, Tennessee 37831-6335.

Strathmann, R. R. 1967. Estimating the organic carbon content of phytoplankton from cell volume or plasma volume. Limnol. Oceanogr. 12, 411-418.

Takahashi, T. 1989. The carbon dioxide puzzle. Oceanus 32, 22-29.

Thompson, L. G., Mosley-Thompson, E., Davis, M. E., Lin, P.-N., Henderson, K. A., Cole-Dia, J., Bolzan, J. F. and Liu, K.-B. 1995. Late glacial stage and Holocene tropical ice core records from Huascarán, Peru. Sience 269, 46-50.

Tortell, P. D., Reinfelder, J. R. and Morel, F. M. M. 1997. Active uptake of bicarbonate by diatoms. Nature 390, 243-244.

Urey, H. C. 1947. The thermodynamic properties of isotopic substances. J. Chem. Soc., 562-581.

Vengosh A., Kolodny, Y., Starinski, A., Chivas, A. R. and McCulloch, M. T. 1991. Coprecipitation and isotopic fractionation of boron in modern biogenic carbonates. Geochim. Cosmochim. Acta 55, 2901-2910.
Volk, T. and Hoffert, M. I. 1985. Ocean carbon pumps: analysis of relative strengths and efficiencies in oceandriven atmospheric $\mathrm{CO}_{2}$ changes. In: The carbon cycle and atmospheric $\mathrm{CO}_{2}$. Natural variations archean to present (eds. Sundquist, E. T. and Broecker, W. S), pp. 99-110. Geophysical Monograph 32, American Geophysical Union, Washington, DC.

Wolf-Gladrow, D. A. and Riebesell, U. 1997. Diffusion and reactions in the vicinity of plankton: a refined model for inorganic carbon transport. Marine Chemistry 59, 17-34.

Wolf-Gladrow, D. A., Bijma, J. and Zeebe, R. E. 1999. Model simulation of the carbonate system in the microenvironment of symbiont bearing foraminifera. Marine Chemistry 64, 181-198.

Wollast, R. 1994. The relative importance of biomineralization and dissolution of $\mathrm{CaCO}_{3}$ in the global carbon cycle. In: Past and present biomineralization processes: considerations about the carbonate cycle (ed. Doumenge, F.), pp. 13-35. Musée Océanographique, Monaco.

Zeebe, R. E., Bijma, J. and Wolf-Gladrow, D. A. 1999. A diffusion-reaction model of carbon isotope fractionation in foraminifera. Marine Chemistry $\mathbf{6 4}$, 199-227. 